\title{
PLATÃO E A PEDAGOGIA DO RISO
}

José André Ribeiro*

\section{RESUMO}

A principal hipótese deste trabalho é que Platão utiliza o riso como uma ferramenta pedagógica no diálogo Eutidemo. Procuramos evidenciar como o autor busca despertar no leitor a atenção para o comportamento risível dos dois irmãos sofistas, Eutidemo e Dionisodoro. Trata-se de evidenciar o resgate que o autor faz do personagem cômico de Sócrates para contrastar com esses sofistas, pois isso possui uma razão simultaneamente pedagógica e filosófica. O intuito é demonstrar que, na maior parte das vezes, as interpretações tradicionais tendem a subestimar os elementos cômicos nos diálogos platônicos, sobretudo ao tratar o autor como uma espécie de "domesticador do riso".

Palavras-chave: Platão, sofistas, cômico, pedagogia, riso.

* Instituto Federal de Educação, Ciência e Tecnologia da Bahia (IFBA), Porto Seguro/BA, Brasil. 


\section{PLATÓN Y LA PEDAGOGÍA DE LA RISA}

\section{RESUMEN}

La principal hipótesis de ese trabajo es que Platón utiliza la risa como una herramienta pedagógica en el diálogo Eutidemo. Procuramos resaltar como el autor busca despertar en el lector la atención para el comportamiento risible de los dos hermanos sofistas, Eutidemo y Dionisodoro. Se tratase de evidenciar el rescate que el autor hace del personaje cómico de Sócrates, para ser contrastado con estos sofistas. Esto hay una razón simultáneamente pedagógica y filosófica. El objetivo es demostrar que, en la mayoría de los casos, las interpretaciones tradicionales tienden a subestimar los elementos cómicos en los diálogos platónicos, especialmente cuando se trata al autor como una especie de "domesticador de la risa”.

Palabras clave: Platón, sofistas, cómico, pedagogia, risa.

\section{PLATO AND THE PEDAGOGY OF LAUGHTER}

\section{ABSTRACT}

The main hypothesis of this work relies on how Plato uses laughter as a pedagogical tool in the dialogue Euthydemus. We emphasize how the author draws the reader's attention to the risible behavior of the sophist brothers, Euthydemus and Dionysodorus. We intend to evince how Plato retrieves Socrates' comic character in order to contrast him with the sophists. The explanation for this is simultaneously pedagogical and philosophical. The aim is to demonstrate that traditional interpretations always tend to underestimate the comic elements in Platonic dialogues, especially when treating the author as a kind of "tamer of laughter".

Keywords: Plato, sophists, comic, pedagogy, laughter.

\section{PLATON ET LA PÉDAGOGIE DU RIRE}

\section{RÉSUMÉ}

L'hypothèse principale de ce travail consiste à montrer que Platon utilise le rire comme un atout pédagogique dans le dialogue Euthydème. Nous soulignons comment l'auteur attire l'attention du lecteur au comportement risible des frères sophistes, Euthydème et Dionysodore. Il s'agit de mettre en évidence comment l'auteur récupère le personnage comique de Socrate afin de le contraster avec les sophistes. Cela a une explication simultanément pédagogique et philosophique. Le but est de démontrer que les interprétations traditionnelles ont toujours tendance à sous-estimer les éléments comiques des dialogues platoniciens, surtout quand on traite l'auteur comme une sorte de «dompteur du rire».

Mots-clés: Platon, sofistas, comique, pédagogie, rire. 


\section{INTRODUÇÃO}

É comum estabelecer um paralelo entre Sócrates, de um lado, como o típico personagem bufão e cômico, que usa da ironia como artefato argumentativo para incentivar seus interlocutores a buscar a verdade1; enquanto, do outro lado, contrariando a imagem do mestre, estaria Platão, o filósofo que encontra no riso um tipo de afeto que conduz os indivíduos a gozarem de emoções extremas e, por isso, necessita ser controlado e domesticado ${ }^{2}$. Esse é o tipo de interpretação que gostaríamos de criticar neste trabalho, especialmente quanto ao segundo ponto. O intuito é não somente mostrar a impossibilidade de se promover cisões dicotômicas radicais entre o mestre e o discípulo, ou melhor, entre personagem e autor; mas, sobretudo, apresentar o modo como Platão defende a possibilidade do riso ser utilizado como ferramenta pedagógica, pelo menos em um diálogo em particular, o Eutidemo.

Vamos analisar esse ponto de vista, que será objeto de nossa crítica, a partir de algumas referências historiográficas. De início, citamos o livro História do Riso e do Escárnio, de George Minois (2003, p. 64-72). Na primeira parte dessa obra, vemos o autor abordar as diferentes concepções do uso do riso na tradição grega, situando Sócrates como o filósofo que fez dele um instrumento irônico, cuja finalidade seria prestar um serviço para a busca da verdade (2003, p. 49). É nítido o reconhecimento do historiador do riso irônico como uma marca fundamental da filosofia socrática. Nessa perspectiva, a tese exposta é a de que o riso ocupa, na filosofia socrática, um papel determinante como ferramenta pedagógica.

Entretanto, sem vincular necessariamente a filosofia socrática aos

\footnotetext{
${ }^{1} \mathrm{~A}$ noção de ironia associada à comicidade de Sócrates é notada desde a antiguidade. Mas, para o que nos interessa, basta ver uma observação de Kierkegaard (2013, p. 67), em O conceito de Ironia, na qual ele afirma que o personagem Sócrates, do diálogo Banquete de Platão, é "a imagem plástica da unidade abstrata do cômico e do trágico". O que, de fato, remete-nos ao tropo clássico da ironia socrática como elemento literário de ambivalência tragicômica.

${ }^{2}$ Geralmente, esse tipo de interpretação escora-se, sobretudo, na passagem da República em que Sócrates censura o riso na educação dos guardiões (388e).
} 
diálogos platônicos, Minois (2003, p. 55) afirma que Platão, em suas obras, buscou eliminar o caráter de agressão, típico do riso arcaico e homérico, elevando-o a um patamar intelectualizado. Nesse viés, é como se Platão transportasse o riso da esfera pessoal para o campo argumentativo, não para destruir interlocutores (2003, p. 55), mas para confrontar argumentos. Sendo assim, ele estaria entre os autores denominados por Minois como "apáticos"3, cuja característica principal consiste no ímpeto de tentar controlar as emoções do riso. Ou seja, Platão estaria no grupo de autores que rejeita o uso irrefletido do riso, tentando estabelecer um policiamento. O que, na interpretação de Minois, implica na iniciativa de desconfiar do caráter extremo do riso enquanto afeto:

Todavia, é em Platão que se deve procurar uma argumentação de princípio contra o riso. O riso não está ausente de seus diálogos: Sócrates e seus interlocutores riem várias vezes; é possível encontrar histórias engraçadas (...). Contudo, Platão desconfia do riso, cuja natureza ambivalente é inquietante. É uma paixão que perturba a alma e que pode estar ligada, ao mesmo tempo, ao prazer e à dor. (2003, p. 70).

Como é evidenciado, apesar de se reconhecer que nos diálogos existe um uso de passagens cômicas, em vista do riso, a perspectiva interpretativa de Minois é a de considerar que para o filósofo o uso desse afeto dever ser ponderado, tendo uma função somente acessória. É como se para Platão o riso não possuísse qualquer importância de teor filosófico, ou, até mesmo, pedagógico. Sendo assim, o filósofo seria um dos principais representantes da tentativa de domesticação do riso, transportando-o para uma finalidade apenas figurativa e filosoficamente secundária: rir do absurdo dos argumentos dos inimigos, dos seus vícios e defeitos morais. Para Minois, o uso platônico do riso tem um caráter "parcimonioso a serviço da moral e do conhecimento" (2003, p. 72).

3 Cf. o subtítulo do capítulo "Os apáticos, de Pitágoras a Platão" (2003, p. 69). 
De modo semelhante, Verena Alberti (2002, p. 41-46), ao analisar o Filebo e a República considera que o movimento de análise do filósofo tem como principal intuito fazer com que a "razão" freie o riso. Trata-se de uma leitura muito literal das considerações de Sócrates a respeito do riso, em ambos diálogos, principalmente nos pontos em que surgem elementos de uma "psicologia do riso", na qual ele aparece definido como um "falso prazer" da alma, ou simplesmente como uma afeç̧ão ou paixão que devesse ser rigidamente controlada pela alma. As considerações que Alberti (2002, p. 41) faz tem um duplo aspecto, de início, para reconhecer que em Platão, historicamente, encontramos a primeira formulação teórica sobre o riso; depois, para situá-lo como um de inimigo racionalista do riso, cujo projeto seria o de promover uma submissão do riso à filosofia. Isso é o que podemos observar em considerações como a que se segue:

Combinando as observações de $A$ República e de Filebo, podemos
concluir que o conceito negativo que Platão faz do riso e do risível é
determinado, em última análise, por sua concepção da filosofia como
prazer puro e única forma de apreensão da verdade, em oposição à
ilusão característica das paixões. O riso e o risível seriam prazeres
falsos, experimentados pela multidão medíocre de homens privados
da razão. (ALBERTI, 2002, p. 45-46)

Além disso, vemos sempre a iniciativa de fazer da filosofia platônica algo semelhante a um filtro racionalista, que funcionaria como uma razão estética, inaugurando a prerrogativa de que o riso, em si, é feio (MINOIS, 2003, p. 73). Diante disso, seria possível apontar uma dicotomia entre a postura dos filósofos de influência platônica e a dos homens comuns, apreciadores das comédias apresentadas nos festivais: "enquanto os filósofos expressam gravemente sua hostilidade em relação ao riso, os gregos - e os outros divertem-se como se isso não existisse" (MINOIS, 2003, p. 73).

Bremmer (2000, p. 24), nesse aspecto, cita Platão e Aristóteles como exemplos de pensadores que se opõem ao modelo obsceno e bufão do riso 
cômico tradicional4, na medida em que eles combatem o tipo de humor grosseiro que encontramos na literatura cômica. Em relação a Platão, ele cita os trechos da República (388e e 606a-e) para mostrar que o filósofo coloca certa ênfase em uma "moderação" do riso, na qual se critica o riso exagerado da poesia cômica, como um tipo de reação violenta, que precisa ser controlada.

Nossa crítica a esse tipo de interpretação tem dois direcionamentos: 1. quanto a Sócrates, há certo sentido na interpretação da figura bufônica dele, porém, se exagera a correlação entre ironia e riso, sem apontar o real sentido filosófico da comicidade do personagem; 2. quanto a Platão, o erro tem uma forma grosseira de não perceber a sutileza no uso das piadas e das cenas engraçadas nos diálogos, especialmente por não alcançar o sentido sutil dessas em despertar o interesse do leitor para o caráter e o comportamento dos personagens e a sua correlação com elementos argumentativos e filosóficos. Esse modelo de interpretação se equivoca ao não perceber que, de modo implícito, a mensagem mais contundente dos diálogos platônicos é mostrar como os recursos literários estão disponíveis para a realização do discurso filosófico.

A princípio, acreditamos que esses erros são o resultado de uma forma muito literal de se fazer leituras dos diálogos, pois é possível, de fato, encontrar passagens em que o autor coloca seu principal personagem, Sócrates, tecendo críticas a determinados tipos de uso do riso e do cômico. Porém, mesmo diante disso, podemos também extrair dos diálogos uma separação entre dois modos de se utilizar o riso: o riso a serviço de um objetivo pedagógico e o riso da pura zombaria. Isso nos permitiria observar uma estratégia interpretativa que prova que Platão tem uma preocupação de transformar o riso em ferramenta pedagógica, não simplesmente domesticando-o e submetendo-o ao sério. Para corroborar com essa perspectiva, vamos fazer o seguinte itinerário: 1. mostrar a comicidade ambígua do personagem Sócrates; 2. expor trechos do Eutidemo nos quais o riso aparece sendo contextualizado; 3. extrair dessas duas

4 Cf. o subtítulo do capítulo “A domesticação da bufonaria e do riso” (BREMMER, 200o, p. 23). 
demonstrações uma perspectiva de Platão sobre o uso do riso.

\section{SÓCRATES COMO PERSONAGEM CÔMICO}

O primeiro passo da nossa interpretação é tentar mostrar certa natureza ambígua na representação cômica de Sócrates, como uma espécie de personagem simultaneamente ridículo e louvável, cujo terreno originário foram as comédias. Essa ambiguidade origina-se de um jogo cênico entre censura e elogio que aparece nas comédias e depois vai se convertendo em algo decisivo para a representação do personagem.

Em vista disso, vamos recorrer a uma representação cômica de Sócrates que se encontra no livro IV das Tusculanas, de Cícero. Nela, o autor narra uma anedota sobre a feiura física e o desleixo quanto à aparência do personagem. As referências aos traços físicos de Sócrates, como o nariz adunco, lábios grossos e olhos esbugalhados, além de um comportamento muito fora do convencional, têm uma natureza caricatural clara, o que, de certo modo, procura representá-lo como alguém risível5. Como se sabe, o apelo à feiura física é um dos elementos originários das comédias, que tem a ver com a figura mítica dos sátiros e com o uso de máscaras nos dramas satíricos (BRANDÃO, 1980, p. 85). Isso, de certo modo, articula dois elementos da comicidade grega: a fusão entre a feiura física e o declínio moral.

O relato de Cícero conta que o fisionomista Zopiro, certa vez, fez uma análise do rosto e da aparência de Sócrates para mostrar que seu caráter moral era harmônico com sua feiura física. Zopiro teria feito uma lista dos defeitos de Sócrates e apresentado para um público, que riu e debochou não do filósofo, mas da exposição do fisionomista. Segundo Cícero, o público riu porque achou que a lista de defeitos feita por Zopiro mais elogiava do que ridicularizava

\footnotetext{
5 Nesse aspecto, há duas caracterizações relevantes de Sócrates como o típico feio e desleixado: Nuvens (v. 101-103, v. 414-420) e Teeteto (143e).
} 
Sócrates. Isso nos mostra que a ambiguidade física e moral do filósofo tem um caráter simultâneo entre censura e elogio. O paralelo aludido, nesse caso, é entre kallokagathia, como elemento de fusão entre beleza física e retidão moral; assim como à kakokagathia, que é a noção de que a feiura física geralmente vem associada a um declínio moral. Como se sabe, na tradição homérica, um dos princípios da paideia era a busca da kallokagathia, que consiste em formar nos homens nobres a plena fusão entre o estético e o ético, isso é, entre o belo e o bom. Com efeito, o feio é representado como o contrário disso: a fusão entre o declínio físico e o moral, entre o feio e o mau. Disso provêm a comicidade característica da representação do feio, que encontra seu exemplo mais claro no paralelo feito na Ilíada (II, v. 211-271) entre os belos e bons, Aquiles e Odisseu, e o feio, tosco e corcunda Tersites, um dos ícones tanto da feiura física, quanto da falta moral.

Porém, no caso de Sócrates, esse paralelo se desfaz, já que podemos rir da sua feiura física, mas não do seu caráter. Como se observa na anedota de Cícero, quem se torna motivo de riso é Zopiro, e não o filósofo. Por isso, é cabível uma explicação de Sócrates a Zopiro sobre o que levou o público a rir: apesar dos seus defeitos físicos evidentes, o filósofo dedicou sua vida inteira a corrigi-los, ou melhor, a disfarçá-los a partir da prática constante de exercícios da alma, ou seja, da sua dedicação à filosofia.

Em seu livro História da Feiura (2007, p. 28), Umberto Eco interpreta, nessa perspectiva, a analogia de Sócrates com as estátuas dos silenos feita no Banquete (215b). Para ele, a analogia demonstra uma ruptura dessa dicotomia entre o belo e o bom de um lado e do feio e o ruim do outro. Essa associação do Banquete (215b), para ele, faria um jogo interessante entre feiura externa (nariz adunco, lábios grossos e olhar taurino) e beleza interna (dedicação plena a atividades de pensamento voltadas para um cultivo da alma). Como se sabe, os silenos são uma espécie de personagens míticos de sátiros envelhecidos, nas quais a descrição da feiura física vem de uma representação zoomorfa da fusão entre homem e bode. Essa comparação com os silenos cumpre a função de 
estabelecer um elo entre externo, feio, e interno, belo. Disso se pode deduzir uma peculiaridade do filósofo como uma espécie de quebra da visão tradicional da kallokagathia, na qual se representa um paralelo entre ela e a kakokagathia. Sócrates é um personagem que mistura a feiura física dos sátiros ao caráter divino da filosofia (Banquete, 215b). A beleza de Sócrates, então, não tem um caráter externo, manifestando-se não no corpo, mas no interior, na alma. $\mathrm{O}$ filósofo é belo e bom, principalmente em suas palavras e ações. Nesse aspecto, ele representa o encontro perfeito entre o feio e o belo, e entre a censura e o elogio, já que, pode ser simultaneamente ridículo por sua aparência física e louvável por ser alguém que se dedica a buscar o bem da alma.

Além dessa referência, podemos observar uma exposição feita em Diógenes Laércio (II, 5, 27), na qual ele cita um trecho das Nuvens (v. 412-417 e v. 362-363) para retratar essa mesma ambiguidade de Sócrates como uma típica figura cômica e louvável. Pelo que se percebe na exposição, Diógenes Laércio, em primeiro lugar, faz uma alusão à definição de comédia que encontramos na Poética, de Aristóteles (1448a, 1448b, 1449a-b), para anunciar o modo de operação narrativa que ele busca na representação de Sócrates. Como se sabe, a definição de comédia da Poética é a de que o cômico se formata a partir da depreciação dos personagens; isso é, da "imitação de caracteres inferiores" (mimesis phauloteron). Nesse sentido, a estratégia cênica das comédias seria a de expor os personagens por meio do seu caráter vergonhoso e ridículo (aischros). É nessa perspectiva que Diógenes Laércio (II, 5, 21) nos dá uma descrição de Sócrates digna de análise:

Frequentemente em suas investigações, ao dialogar com uma certa violência, golpeavam-no ou arrancavam-lhe os cabelos; a maioria o despreza rindo (to pleon te gelasthai kataphronoumenon): e tudo isto suportava com paciência (kai panta tauta pherein anexikakos). E uma vez quando foi chutado, alguém se espantou, depois que ele se reergueu e disse: "Se um jumento me chuta, deveria levá-lo à 
justiça?”(ei de me onos elaktise, diken an auto elagchanon) ${ }^{6}$.

Há, nesse trecho, dois aspectos interessantes da encenação da violência, semelhante às comédias aristofânicas, que são: 1. o uso da linguagem como recurso burlesco; 2. a representação de uma violência física7. A cena descrita na narrativa de Diógenas Laércio é extremamente exagerada. A imagem decorrente é a de que Sócrates era extremamente violento no seu jeito de falar e, por isso, também era vítima de uma violência física grotesca por parte dos seus interlocutores. Contudo, o que na comédia seria uma encenação cômica, aqui torna-se uma anedota. O intuito parece ser mostrar como Sócrates era "capaz de desprezar aqueles que zombavam dele" (II, 5, 27) por meio de uma narração anedótica, cuja desenvoltura é testemunhar um tipo de desdém, com uma sutil mensagem pedagógica. $\mathrm{O}$ efeito cômico dessa anedota expõe um duplo aspecto do filósofo: agressividade e desprendimento. Apesar de ser apresentado simultaneamente como agressor e como vítima de agressão, Sócrates traz uma mensagem pedagógica ao mostrar ao seu agressor o efeito ridículo da sua agressão. O filósofo é motivo de riso por ser agredido, assim como transforma o outro em objeto de riso ao debochar da agressão. Esse é o sentido do desprezo do filósofo pela agressão de que é vítima.

Além disso, é interessante notar que a resposta à violência como recurso cômico vem através de outro recurso, também cômico: comparar seres humanos com animais. Aquele que agride é comparado a um jumento. Logo, é inferior ao filósofo, por se comportar como um animal. Sócrates argumenta de forma violenta, mas quem não consegue com ele dialogar age com a agressividade de um animal. Em seguida, a própria anedota tenta trazer à tona uma breve representação do sentido da justiça: deveria alguém superior levar o inferior a um tribunal por agredi-lo ao não conseguir manter um diálogo? Essa mensagem

\footnotetext{
${ }^{6}$ Todas as citações de Diógenes Laércio serão feitas a partir da tradução de Mario da Gama Kury, seguidas do texto grego transliterado nos trechos que julgarmos relevantes a presença dos termos gregos.

7 Cf. Andò (2011, p. 55-67) para uma estratificação do uso da violência como recurso cômico em Aristófanes.
} 
anedótica indica um sentido: o superior deve ser tolerante com a agressividade do inferior, o ser humano não pode interpretar mal a agressão de um animal. Em suma, o especialista ou o mestre deve ser paciente com o ignorante, ou discípulo.

Como se vê, o trecho não se reduz a uma representação do caráter inferior de Sócrates para apresentar uma cena cômica. De certo modo, o intuito de Diógenes Laércio é mostrar de forma cômica um comportamento exemplar do filósofo. Para tanto, a observação dele é a de que os comediógrafos, ao tentarem ridicularizar o comportamento do filósofo naquilo que ele tem de altivo e ascético, também promovem um elogio a ele, de forma indireta. Ou seja, os poetas cômicos, ao ridicularizarem, representam aspectos louváveis do comportamento do filósofo.

Em decorrência dessa descrição, pode-se formular um fundamento pedagógico de Sócrates, como personagem simultaneamente sério-cômico. Esse personagem, nessa perspectiva, pode ser representado como um modelo pedagógico sério, enquanto alguém que deve ser visto em suas palavras e ações, porém também com um sentido cômico, devido à feiura física e aspecto debochado e zombeteiro. Diante disso, pode-se formular certa cisão entre cômico e comédia, constatando que não existe um monopólio da comédia sobre o cômico. É isso que garante a possibilidade de criação cômica nos diálogos socráticos, que seriam obras dramáticas simultaneamente sérias e cômicas. É essa a afirmação de Clay (1994, p. 41) sobre como os diálogos socráticos são dotados de uma influência incontornável da comédia ática. Para Clay (1994, p. 38), o primeiro testemunho que se possui de um diálogo socrático é uma imitação das Nuvens (v. 482-88), que demonstra como a comédia aristofânica serviu de modelo para a conversação socrática, delineando elementos que se encontram em escritores posteriores, sobretudo os socráticos. Nessa perspectiva, a comédia define a estrutura do modelo de criação dos personagens, que chega nos diálogos socráticos ganhando também um contorno filosófico. Por isso, a visão geral desse tipo de interpretação é que os diálogos 
seriam composições dramáticas que fundem a utilização de recursos poéticos com debates conceituais. Nightingale (2000, p. 60-61), por exemplo, mostra como a confluência entre a filosofia e os gêneros poéticos é relevante para interpretar a famosa passagem da querela entre filosofia e poesia na República (607b). Para ela, Platão transforma a filosofia em um projeto intelectual de caracterização do filósofo no ambiente cultural da poesia. Por isso, é possível situar as remissões à comédia em paralelo com os outros gêneros: o épico e o trágico. Historicamente, diz Clay (1994, p. 41), é possível destacar a influência predominante das comédias nos diálogos, em detrimento da comparação com os mimos sicilianos. A primeira constatação é o fato de Sócrates ser esse personagem ambíguo, no qual comicidade e seriedade se intercalam. Essa é a interpretação que Clay (1994, p. 41) lança sobre esse testemunho de Diógenes Laércio, na qual se mostra a confluência entre o cômico e a atividade filosófica, representando o filósofo como um típico fenômeno sério do riso. Seguindo essa perspectiva, promoveremos a interpretação de um diálogo platônico específico, o Eutidemo.

\section{O CÔMICO NO EUTIDEMO}

O Eutidemo é um diálogo socrático de caráter explicitamente erístico ${ }^{8}$. Trata-se de Sócrates contando ao seu amigo, Críton, um encontro, no dia anterior, entre ele e dois irmãos sofistas, Eutidemo e Dionisodoro, no qual

\footnotetext{
8 O diálogo tem uma estrutura aporética, posto que não possui uma proposta teórica explícita, fato que o aproxima dos ditos diálogos de juventude, porém, também possui uma correlação implícita com outros diálogos tardios, sobretudo República, Fédon e Fedro. Por isso, encaixálo no enquadramento cronológico e desenvolvimentista do corpus platonicum é extremamente difícil. Cf. Palpacelli (2009, p. 33-38) para os pormenores do problema cronológico e, também, Chance (1992, 2-10) para inúmeras perspectivas de tentar encaixá-lo no ordenamento do corpus. Nossa opção teórica é de que não é crucial para a sua interpretação encaixá-lo no ordenamento cronológico e na sua correlação com outros diálogos, podendo interpretá-lo à luz de sua intertextualidade com o personagem Sócrates das comédias, percebendo que sua estrutura é simplesmente erística, isso é, traz para o leitor um conjunto de argumentos erísticos, que Platão quer nos colocar como típico da atuação dos dois personagens sofistas, Eutidemo e Dionisodoro.
} 
houve uma disputa argumentativa e uma exibição de jogos argumentativos por parte dos sofistas9. No contexto dramático, encontra-se encenado dois tipos de público: 1. os discípulos dos sofistas, representados por vários jovens no ginásio, que cumprem a função de aplaudir e louvar os irmãos, como um típico público de espetáculos; 2. a dramatização dos jovens que acompanhavam Sócrates, representando certo interesse pela filosofia, que são Ctesipo e Clínias.

A desenvoltura erística do diálogo promove a encenação de como os irmãos sofistas executam uma série de estratégias argumentativas, que causam confusão nos interlocutores. É por isso que Chance (1992, p. 3) afirma que o diálogo funciona como uma demonstração dos procedimentos argumentativos. De certo modo, o que se deduz disso é que o Eutidemo não incide sobre conceitos filosóficos e também não apresenta uma proposta filosófica nitidamente delineada (CHANCE, 1992, p. 3). Isso faz com que o diálogo seja, por vezes, mal interpretado e subestimado, como uma "simples brincadeira argumentativa" (CHANCE, 1992, p. 3). Segundo Chance (1992, p. 13-18), para não se subestimar o Eutidemo, é preciso considerá-lo como "uma completa e acabada obra de arte". Nesse sentido, elucida o autor (1992, p. 14), a interpretação do diálogo deve estar aberta a perceber seus elementos dramáticos, sobretudo naquilo que o aproxima das tragédias e comédias. Seguindo isso, nossa análise vai se concentrar especificamente sobre alguns recursos cômicos.

O primeiro recurso que queremos mostrar é como o diálogo apresenta o tipo de brincadeira argumentativa feita pelos sofistas. O que, inevitavelmente, traz uma representação do que Platão quer que vejamos a respeito da erística. Em 298d-e, observa-se uma encenação interessante do jogo de linguagem que o filósofo quer nos mostrar:

\footnotetext{
9 É interessante notar que o diálogo tem também uma estrutura narrativa, apesar de já se iniciar na forma dialogada, a partir de uma pergunta de Críton a Sócrates: "Quem era aquele com quem conversavas ontem no Liceu, Sócrates?”. Nesse caso, observa-se dois planos no Eutidemo: no presente, diálogo entre Sócrates e Críton e, no passado, a narrativa de Sócrates a Críton sobre o diálogo entre ele e os irmãos sofistas.
} 
D. Diz-me, pois: tens um cão (esti soi kyon)?

C. E muito feroz - respondeu Ctesipo.

D. E sem dúvida tem cachorrinhos (estin oun autoi kynidia)?

C. Que também são outros que tais (etera toitauta).

D. Portanto, o cão é pai deles (pater estin auton o kyon)?

C. De certeza. Eu próprio o vi a cobrir a cadela.

D. Aí sim? E o cão não é teu (ou sos estin o kyon)?

C. Absolutamente.

D. Então, ele é teu, sendo pai (pater on sos estin), de modo que o cão passa a ser teu pai (oste sos pater gignetai o kyon) e tu irmão dos cachorrinhos (kai su kynarion adelphos)? (298d-e) ${ }^{10}$

Nesse trecho, é inegável a tentativa de Platão de conseguir um efeito cômico. A conclusão de que Ctesipo é filho dos seus próprios cães é não só improvável, como sem qualquer referência argumentativa plausível e séria. Qual o intuito de mostrar que, com recursos da linguagem, é possível dizer que alguém pode ser colocado como filho do seu próprio cão, pelo simples fato linguístico de poder afirmar que ele é seu? Claro que o autor do diálogo quer ridicularizar, de forma paródica, esse tipo de estratégia argumentativa, especialmente diante do olhar do leitor. Sendo assim, a estrutura da cena busca o riso pela representação do caráter ridículo da estratégia argumentativa utilizada por Dionisodoro. Isso nos mostra uma posição de Platão diante da erística como produtora de argumentos sem sentido, cujo objetivo seria somente causar embaraço nos interlocutores, sem qualquer objetivo pedagógico ou filosófico explícito. A estratégia é demonstrar uma invencibilidade (amacho) através de discursos belos e terríveis (kalou logou e deinon logon) como se vê em 303a-c:

$\mathrm{Eu}$, como que abatido pelo argumento, fiquei imóvel, sem voz (ekeimen aphonos). Entretanto veio Ctesipo em meu auxílio e disse: -

\footnotetext{
${ }^{10}$ As citações do Eutidemo são feitas a partir da tradução de Adriana Nogueira (1999), seguidas com trechos do texto grego transliterado, nos momentos em que se julgar pertinente a presença dos termos em grego. A edição do texto grego utilizada é a de Burnet.
} 


\begin{abstract}
Bravo, Héracles, que belo argumento (kalou logou)! E vai daí Dionisodoro: - Explica-me: Héracles é que é bravo, ou o bravo que é Héracles? - perguntou Dionisodoro. - Ó Posídon! - exclamou Ctesipo. - Que raciocínios espantosos (deinon logon)! Retiro-me: estes dois homens são imbatíveis (amacho to andre).
\end{abstract}

É nítido que a cena mostra como os argumentos dos sofistas conduzem a jogos absurdos: pegar uma interjeição (Bravo, ó Héracles!) e brincar com a alternância nos termos que formam a frase, na relação predicativa, invertendo o sentido declarativo (Héracles é bravo) no de adjetivação (bravo é Héracles) ${ }^{11}$. Os irmãos, nesse caso, representam um tipo de conduta pedagógica totalmente calcada em um tipo de espetáculo, que consiste em fazer brincadeiras com o sentido e a ambiguidade no uso das palavras e das frases para atrair o olhar dos espectadores.

Por conseguinte, observa-se que há um uso frequente dos termos da família de paidia, que é um correlato do termo pais (criança), e pode ser traduzido genericamente como "jogo de criança", ou simplesmente "brincadeira". De todo modo, esse termo remete a algo de roupagem infantil, pueril, ou até mesmo de gracejo. É claro que o termo apresenta um contraste com o termo paideia (educação) e, em alguns trechos do diálogo ${ }^{12}$, denota uma intenção educativa dos jogos argumentativos feitos pelos irmãos sofistas. Tanto que, no contexto narrativo do diálogo, o que vemos é Sócrates tentando convencer seu amigo, Críton, a se tornar junto com ele discípulo dos sofistas, com o intuito de aprender as regras desses jogos argumentativos, isso é, a erística (272b-d).

No contexto geral do diálogo, percebe-se a iniciativa de Platão de criar uma imagem da erística como simples brincadeira. Em primeiro lugar, por

\footnotetext{
${ }^{11}$ Esse jogo fica mais evidente em grego por causa do uso explícito do verbo einai (ser) na primeira formatação, "o Erakles pyppax estin", e o uso implícito com sentido mais adjetivo do termo pyppax em "o pyppax Erakles".

${ }_{12}$ Aparece paideia no início do diálogo, em 272d, depois no meio, em 290e, por fim, em 306e. O termo paidia vem sucessivamente em 277d, 278b, 291b, 294e, 307c, além de paidikos em 283e e $300 c$.
} 
situá-la em um ambiente típico da juventude ateniense, um Liceu (271a), que é uma espécie de ginásio, cujo espaço especificamente pedagógico é utilizado para se aprender e executar atividades físicas, como jogos ou brincadeiras (paidiai). Em segundo lugar, ao dramatizar o diálogo nesse cenário, o filósofo parece representar a presença invasiva dos jogos argumentativos em um ambiente típico da padieia ateniense, destacando sua falta de contexto nesse ambiente. De certo modo, isso nos mostra que a erística está, de fato, fora de seu lugar, reforçando o olhar do leitor para a semelhança entre os jogos argumentativos e as brincadeiras.

Contudo, há um destaque para o teor espetacular dos jogos com as palavras, que cria um sutil contraste com a arte da ginástica. Enquanto a segunda tem objetivos específicos através dos seus jogos, que é principalmente a formação de um corpo saudável; a primeira não ensina algo cujo conteúdo ultrapasse a brincadeira. A erística é uma pura brincadeira, somente um jogo com palavras e argumentos, sem um real objetivo pedagógico. Isso é o que decorre do modo como Platão organiza as cenas do diálogo: um intercâmbio entre os termos paidia (brincadeira), spoudaios (sério), geloios (ridículo) e katagelao (risível) ${ }^{13}$. O que se pode dizer quanto a esse contraste é que o diálogo contextualiza essa correlação entre o jogo e o sério para pensar a paideia. Devese procurar algo spoudaios em uma paidia, pois, se ela não é séria, será obviamente ridícula e risível, não sendo apropriada para se aprender. Isso demonstraria o limite pedagógico do modelo argumentativo apresentado pelos sofistas.

Como se observa, o projeto deles é promover uma exibição que visa simplesmente atrair o aplauso dos jovens, para lhes conquistar como discípulos. Vemos, com isso, uma representação da ação do público diante desse tipo de estratégia - de rir e aplaudir -, principalmente vindo do público jovem, que Platão quer mostrar como mais afeito aos espetáculos. É isso que se observa em

\footnotetext{
${ }_{13}$ Aparece spoudaios em contraposição à paidia em 283b-c, 288c-d, 293a e 294b, o verbo gelao em 276b, 278c-d, 303b e katagelao em 278d-e, 305a e 307b.
} 
276d: "Nesse momento os admiradores (oi erastai) dos dois homens riram e aplaudiram (egelasan te kai ethorybesan) ainda mais, admirando a sabedoria deles. Nós, espantados, ficámos calados”. Há, aqui, duas reações distintas ao espetáculo dos sofistas: de um lado, um público jovem que ri e aplaude, e, do outro, há Sócrates e os outros dois jovens, que se calam. O termo oi erastai (os admiradores, ou os amantes), utilizado para descrever os discípulos dos sofistas, mostra como eles estão cerceados por um tipo de encantamento erótico. É em decorrência disso que Platão caracteriza a erística como uma espécie de "barulho tumultoso" (ethorybesan). Em paralelo, os interlocutores, vítimas dos jogos argumentativos, são descritos como oi alloi (os outros), cabendo-lhes apenas o silêncio. Essas duas reações nos mostram resultados diferentes, porém indicam ao leitor o que a cena evidencia: ver como ridícula a estratégia exibicionista dos sofistas, do mesmo modo que é ridícula a reação apaixonada do público. Os jovens riem dos que se calam e nós, leitores, rimos de como é ridículo o riso deles. Esse é também um jogo, claramente literário, que visa despertar no leitor o riso sobre como é ridículo o que os sofistas fazem, assim como é ridículo admirar esse tipo de argumentação.

Os sofistas criam todas as suas estratégias argumentativas em vista de demonstrarem sua invencibilidade e o termômetro para a comprovação disso é a reação do público. Quanto mais aplausos e euforia do público, mais próximo de vencer o interlocutor. É um comportamento nitidamente centrado no reconhecimento do público, por isso, é necessário construir peripécias que agradem. Esse é o sentido da caracterização feita no prólogo do diálogo dos sofistas como pancraciastas (271c). Em um Liceu, os lutadores de pancrácio exibem-se para demonstrar seu vigor físico e despertar o interesse dos jovens pela luta. Porém, os sofistas lutam com as palavras, não com o corpo.

Em 271d, Sócrates persiste na analogia da luta e descreve as palavras dos irmãos como armas. O que se percebe é a necessidade de Platão de descrever a argumentação erística como um modo de luta disposta a recorrer às armas que forem necessárias para vencer. Além disso, o autor quer deixar claro 
que o intuito desses lutadores com palavras é somente derrubar o interlocutor, sem precisar, para isso, apresentar um conteúdo conceitual ou qualquer sentido pedagógico plausível. Em 227b, a analogia nos mostra que eles fazem discursos como se jogassem com uma bola (277b), e é esse tipo de estratégia que os deixa aptos para lutar contra os oponentes $(277 \mathrm{~d})$.

Como se percebe, a narrativa do Eutidemo também apela para certo exagero na linguagem. É possível perceber isso especialmente nos momentos em que se descreve a relação entre os sofistas e o público. Em 303b, Sócrates afirma que a reação do público aos sofistas foi tamanha que faltou pouco para que as próprias colunas do ginásio aplaudissem os dois irmãos. Esse tipo de descrição, claramente caricatural, aponta no sentido de mostrar o real objetivo dos sofistas: arrancar aplausos eufóricos por meio de estratégias argumentativas sem objetivos claros, cujo modus operandi é causar embaraços na linguagem para confundir o interlocutor. Além disso, em $288 \mathrm{~b}$, vemos o aparecimento do verbo goeteuo para descrever esse tipo de ação dos sofistas; o sentido mais geral do verbo seria "seduzir por meio de magia", apesar de aqui ele expressar a ideia de um "encantamento pela palavra". Observa-se que, na descrição, Platão lança sutilmente uma oposição entre o que os sofistas fazem e uma apresentação pedagógica séria, tal como segue Sócrates, falando com seus jovens interlocutores:

Ctesipo, o que mesmo ainda agora dizia a Clínias, digo-o também a ti, ou seja, que não compreendes que a sabedoria destes forasteiros é extraordinária (oti thaumasia estin). Só que não estão dispostos a fazer-nos uma demonstração séria (epideixasthai spoudazonte), mas imitam simplesmente Proteu, o sofista egípcio, e enganam-nos com as suas artes mágicas (goeteuonte emas). (288b).

Como se vê, a apresentação dos sofistas é "espantosa" (thaumasia), pois causa embaraço nos interlocutores, porém, ela é oposta a uma "exibição séria" (epideixasthai spoudazonte). Essa oposição nos mostra o sentido pedagógico indicado por Sócrates: é possível promover espetáculos espantosos para atrair 
os jovens, todavia, também é necessário fazer exibições sérias. O encantamento por meio de palavras pode ser útil. Entretanto, não pode ser o único recurso pedagógico disponível, limitando-se ao objetivo de vencer o interlocutor a partir de confusões na linguagem.

Disso decorre uma contraposição entre duas perspectivas epistemológicas: a dos sofistas e outra de Sócrates. A primeira tem como ponto central a luta através de jogos da linguagem. A segunda salienta que é necessário não só promover brincadeiras e encantamentos com palavras, mas também é preciso procurar objetivos sérios (288d). Assim, o pressuposto é de que precisamos nos atentar para a localização pedagógica, na qual a aprendizagem e o caminho do conhecimento não estejam submetidos somente àquilo que é agradável aos ouvintes. Como se vê a seguir:

\begin{abstract}
E isto não passa de uma brincadeira de aprendizagem (tauta de ton mathematon paidia estin) - por causa disso é que eu digo que eles estão a brincar contigo (dio kai phemi ego soi toutous prospaizein), e falo em brincadeira (paidian de lego) porque, mesmo que alguém aprenda muitas e mesmo todas estas subtilezas, nem por isso conhecerá as realidades tal como são (ta men pragmata ouden an mallon eideie pei exei); quando muito seria capaz de brincar com as pessoas, usando a diferença das palavras para pregar rasteiras e as fazer cair para traz, como os que puxam por baixo os tamboretes dos que se vão sentar se divertem (chairousi kai gelosin) e riem quando os vêem cair de costas. (278b-c).
\end{abstract}

A analogia apontada por Sócrates é de que aprender as sutilezas argumentativas dos sofistas equivale a reduzir a linguagem à brincadeira, semelhante à ação de aprender a puxar a cadeira de alguém que vai sentar-se, para derrubá-lo e transformá-lo em objeto de riso ${ }^{14}$. A brincadeira em si não ensina nada, é simplesmente uma rasteira. Ou seja, para que possa ensinar algo, a brincadeira deve vir acompanhada de um conteúdo, ou de uma mensagem pedagógica que ultrapasse a própria brincadeira e nos mostre algo em relação às

${ }^{14}$ Cf. Teeteto (174a-175e) para a anedota de Tales de Mileto, na qual o filósofo é tido como objeto de riso por ter caído em um buraco. 
coisas. Essa parece ser uma mensagem pedagógica nítida de Platão para vislumbrarmos como devemos nos comportar na utilização do cômico como ferramenta pedagógica: ele deve ser utilizado para apontar para algo a mais do que a simples mensagem cômica. Ou seja, o cômico é uma ferramenta pedagógica e não se esgota em si mesmo. Não devemos simplesmente aprender as brincadeiras, mas, sobretudo, aprender algo com as brincadeiras. De fato, há uma instrumentalização do riso, não um policiamento ou recusa plena dos seus recursos emocionais, como apontado na interpretação de Minois.

Sendo assim, pode-se enumerar dois movimentos contrários no Eutidemo. Um de sentido aristofânico, por recorrer aos elementos tradicionais da comédia, fazendo uma imitação de personagens de caráter ridículo, no caso os sofistas. O outro, ao contrário, de teor não cômica, pois tenta mostrar uma via alternativa ao ridículo, que pode ser observada na narrativa de Sócrates e no comportamento do seu amigo, Críton, frente às cenas descritas pelo filósofo. Nesse sentido, a postura filosófica de Críton de questionamento sobre o real teor pedagógico das artimanhas erísticas dos irmãos nos mostra como extrair do ridículo um conteúdo que extrapola a piada.

De uma coisa podemos estar certos, o modo como Platão coloca a filosofia no Eutidemo nos leva a ver que ela não se resume a um método argumentativo, como é o caso da atividade exercida por Eutidemo e Dionisodoro. Nesse sentido, cabe a nós leitores conseguir distinguir dois campos de conhecimento distintos: a filosofia e a erística. A primeira teria como objetivo pedagógico tentar conduzir os jovens à prática da virtude, enquanto a segunda apenas se preocupa em conquistá-los com exibições agonísticas. É nesse aspecto que se consegue incluir o Eutidemo na tradição de textos protrépticos, que são peças argumentativas de sentido filosófico e exortativo, para atrair jovens para atividade filosófica. É isso que confere sentido aos alertas feitos por Críton em 304c-d e 306d-e. 


\section{CONCLUSÃO}

No livro Homo Ludens, Johan Huizinga (2014, p. 8-9) tenta situar a definição do lúdico como algo que tende mais para a noção de jogo do que para a de cômico. Na verdade, ele tenta nos mostrar que o cômico não se confunde com as noções de brincadeira, ou jogo. O cômico, diz ele, busca experiências cujo foco é estritamente ligado ao riso (2014, p. 8). Por outro lado, o jogo não teria esse compromisso. Porém, ambos seriam contrapostos ao sério, mesmo que cada um possua certa especificidade. O jogo contrapõe-se ao sério como lúdico, reservando a si a possibilidade de fusão, uma espécie de jogo sério. Entretanto, o riso é especificamente uma não-seriedade. Nesse aspecto, diz Huizinga (2014, p. 164), os jogos argumentativos dos sofistas representam um importante exemplo da mais estreita relação entre o jogo e o sério. É isso que estaria representado no jogo argumentativo do Eutidemo, um tipo de jogo sério. Os sofismas seriam uma espécie de "truque de combatente" (2014, p. 165), com uma mensagem séria subentendida. Todavia, o que parece ser um equívoco nessa interpretação de Huizinga tem dois aspectos: 1. não perceber que o jogo, ou a brincadeira, como Platão encena no Eutidemo, tem um caráter mais cômico do que sério; 2. em decorrência disso, a oposição entre cômico e sério pode ser reestruturada, pois na encenação pode se observar certa localização do riso, voltada para o leitor, que precisa rir das ridículas argumentações dos sofistas. Nesse sentido, Platão, no Eutidemo, encena uma confluência entre a brincadeira e o riso, de forma a demonstrar que ambos podem ser utilizados como ferramentas pedagógicas, desde que isso seja feito de modo sério e com objetivos filosóficos claros. Portanto, nossa tese é de que há, nesse diálogo, uma confluência entre o jogo, o sério e o cômico, na medida em que se encena um intercâmbio entre esses termos no contexto dramático da relação entre Sócrates e os sofistas. A mensagem pedagógica consiste basicamente na seguinte: em vez de seguir as brincadeiras argumentativas dos sofistas, que são ridículas e risíveis, os jovens devem buscar uma postura interrogativa, como as de Sócrates e Críton, que tentam entender os objetivos e os efeitos dessas brincadeiras, 
tanto no sentido argumentativo, quanto filosófico, buscando rir das absurdas argumentações erísticas. É isso que está subentendido na recusa de Críton, quase no final do diálogo (304c-d), de querer se assemelhar aos sofistas:

A verdade, Sócrates, é que sou um bom ouvinte e teria prazer em aprender alguma coisa. No entanto, é provável que eu não esteja no número dos que se assemelham a Eutidemo, mas no dos que tu dizias que preferiram ser refutados a refutar com tais argumentos.

A partir do exposto, observa-se que o comportamento dos dois amigos, Sócrates e Críton, não é vergonhoso, na medida em que buscam ver o que há de sério nas brincadeiras argumentativas dos sofistas e, sobretudo, estão abertos a aprender com elas ${ }^{15}$, naquilo que elas tiverem de valor para a atividade que eles denominam de filosofia.

Os elementos literários do diálogo assemelham-se em alguns recursos às comédias, pois, evidentemente, buscam construir determinadas cenas para conduzir o leitor ao riso. Entretanto, o que, de fato, importa ao olhar socrático é não reduzir a experiência pedagógica ao cômico, mesmo que ele seja um recurso extremamente plausível.

Como se percebe, temos aqui dois formatos diferentes para o riso. $\mathrm{O}$ primeiro é o da piada vazia, cujo intuito não tem uma aparente consequência intelectual no interlocutor, sendo apenas o riso de deboche, sem um conteúdo expresso para além da própria descarga emocional do riso. Contudo, há também o que Halliwell (1991, p. 280) denomina como "riso consequente", que é quando a brincadeira, ou piada (paidia), é utilizada como ferramenta em que se formata uma experiência pedagógica, na qual o resultado esperado é diferente da própria piada. $\mathrm{O}$ "riso consequente" é uma experiência do riso para se alcançar

\footnotetext{
15 Vale ressaltar que a dramatização do diálogo é uma narrativa de Sócrates, de conversa tida no dia anterior com Eutidemo e Dionisodoro, para tentar convencer Críton a acompanhá-lo na tentativa de descobrir o que evidentemente os sofistas ensinam. Ao logo de toda narrativa, há, por parte de Críton, uma desconfiança rígida sobre se tornar discípulo dos dois irmãos, como propõe Sócrates. Cf. no diálogo, especialmente o trecho do início 272b e o do final 304b-c.
} 
processos práticos e sérios, independente da configuração adotada pela piada. Em suma, o riso pode ser usado como ferramenta para uma proposta séria, sobretudo no sentido pedagógico, bastando se situar no seu ambiente específico, no qual a aprendizagem possa cumprir um objetivo determinado. Portanto, isso é uma espécie de determinação do riso como ferramenta pedagógica.

Por isso, o próprio Platão utiliza o riso como ferramenta pedagógica na sua relação com o leitor, ao buscar transparecer e evidenciar o caráter cômico de Sócrates. Porém, o cômico aqui vem acompanhado de uma razão filosófica, de transmitir ao leitor o absurdo de determinados exercícios sofísticos, que nada acrescentam aos seus interlocutores.

\section{REFERÊNCIAS}

ALBERTI, Verena. O riso e o risível na história do pensamento. Rio de Janeiro: Editora Jorge Zahar, 2002.

ANDÒ, Valeria. Violenza ed emozione comica nel teatro di Aristofane.

Ricerche di Storia Antica, n. 3, 2011, p. 55-67.

ARISTÓFANES. As Nuvens. tradução de Gilda Maria Reale Starzynski. São Paulo: Abril Cultural, 1977.

BRANDÃO, Junito de Souza. Teatro Grego: origem e evolução. Rio de Janeiro: Editora Tarifa Aduaneira do Brasil, 1980.

BREMMER, Jan. Piadas, comediógrafos e livros de piadas na cultura grega antiga. In: BREMMER, Jan.; ROODENBURS, Herman. (Org). Uma história cultural do humor. tradução de Cynthia Azevedo e Paulo Soares. Rio de Janeiro: Editora Record, 2000. p. 15-27.

CHANCE, Thomas H. Plato's Euthydemus: analysis of what is and is not philosophy. Berkeley: University of California Press, 1992.

CICERO, Marcus Tullius. Tusculanae disputationes 3 e 4. tradução Margaret Graver. Chicago: The University of Chicago Press, 2002.

CLAY, Diskin. The origins of the Socratic dialogue. In: WAERDT, Paul A. 
Vander (Ed.). The Socratic Movement. Ithaca: Cornell University Press, 1994. p. 23-47.

ECO, Umberto. História da feiúra. Tradução de Eliana Aguiar. Rio de Janeiro: Record, 2007.

HALLIWELL, Stephen. Greek Laughter: A Study of Cultural Psychology from Homer to Early Christianity. Cambridge: Cambridge University Press, 2008.

HUIZINGA, Johan. Homo Ludens: o jogo como elemento da cultura. tradução de João Paulo Monteiro. São Paulo: Perspectiva, 2014.

KIERKEGAARD, Søren. A. O conceito de ironia: constantemente referido a Sócrates. tradução de Álvaro Luiz Montenegro Valls. Petrópolis: Vozes, 2013.

LAÊRTIOS, Diôgenes. Vidas e Doutrinas dos Filósofos Ilustres. tradução de Mário da Gama Kury. Brasília: Editora UNB, 2008.

MINOIS, Georges. História do Riso e do Escárnio. tradução de Maria Elena O. Ortiz Assumpção. São Paulo: Editora UNESP, 2003.

NIGHTINGALE, Andrea Wilson. Genres in dialogue: Plato and the construct of philosophy. Cambridge: Cambridge University Press, 2000.

\section{PALPACELLI, Lucia. L"'Eutidemo" di Platone: uma commedia}

straordinariamente seria. Milano: Vita e Pensiero, 2009.

PLATÃO. Eutidemo. Tradução de Adriana Nogueira. Lisboa: Imprensa Nacional-Casa da Moeda, 1999.

PLATÃO. Eutidemo. Tradução de Maura Iglésias. São Paulo: Loyola, 2011.

PLATÃO. Teeteto. Tradução de Adriana Manuela Nogueira e Marcelo Boeri. Lisboa: Fundação Calouste Gulbenkian, 2010.

JOSÉ ANDRÉ RIBEIRO é doutor em Filosofia pela Universidade Federal do Ceará. Mestre em Filosofia pela Universidade Federal de Minas Gerais. Graduado em Filosofia pela Universidade Federal de Uberlândia. Promove pesquisa nas áreas de Filosofia Antiga, Filosofia Intercultural, Ética e Filosofia Política. Atualmente é professor de Filosofia com Dedicação Exclusiva do Instituto Federal de Educação, Ciência e Tecnologia da Bahia IFBA, no Campus de Porto Seguro. 
Revista História da Educação (Online), 2021, v. 25: e105801

E-mail: joseandre14@hotmail.com

(D) http://orcid.org/0000-0003-2983-3447

Recebido em: 28 de julho de 2020

Aprovado em: 07 de abril de 2021

Editora responsável: Terciane Luchese

(c) (P)

Revista História da Educação - RHE

Associação Sul-Rio-Grandense de Pesquisadores em História da Educação - Asphe

Artigo de acesso aberto distribuído nos termos de licença Creative Commons. 